Obituary

\section{Hubert Curien (1924-2005)}

"M. Hubert Curien is an unassuming, almost shy, man, with the qualities of a terrier" - that was one summary of the personality of the French crystallographer who was among the main architects of both French and European science (see Nature 346, 126-127; 1990). Curien, who died on 6 February at the age of 80 , was one of a rare breed. He was a scientist with an undisputed flair for politics and diplomacy at the highest level, heading up CERN, the European particle physics facility, and the European Space Agency (ESA). For much of a decade, he was also one of the most effective science ministers France has had, enjoying the ear of president François Mitterrand.

But much of Curien's success also resided in his disarming humility, and his wry sense of humour, simplicity and savoir vivre. As a journalist, I was always struck by the fact that, despite the burdens of office, Curien always seemed to have time to discuss and to listen. He was deeply appreciated by the research community, who have fond memories of his terms of office as science minister under four socialist prime ministers - Laurent Fabius (1984-86), Michel Rocard (1988-91), Edith Cresson (1991-92) and Pierre Bérégovoy (1992-93).

His mix of talents allowed Curien slowly, but surely, to take his visions forward, not least his ambitions for European space science and exploration, in the complex context of European politics - where, to this day, national interests and bureaucracy stymie grand ideas. Back in the 1970s, who would have imagined that Ariane, Europe's fledgling rocket launched from ESA's spaceport in Kourou, French Guiana, would grow to dominate the world market and give Europe independent access to space?

Curien was born in Cornimont in the Vosges region of eastern France in 1924; his mother was a headmistress and his father a tax collector. In 1944, he enlisted in the French resistance. The Second World War left a lasting impression on Curien, forging his conviction of the need to construct a European Union.

Starting in 1945, Curien read physics at the Ecole Normale Supérieure in Paris, after which he went on to pursue a research career in crystallography (discovering three crystalline forms of gallium, and having a mineral, curienite, named after him). Throughout his subsequent long political career, he continued to work in his laboratory at the University of Pierre

IMAGE

UNAVAILABLE FOR COPYRIGHT REASONS

\section{Father of the Ariane rocket programme, and champion of a Europe united in science}

and Marie Curie in Paris. Attached to teaching, Curien also maintained his courses at the university until 1994.

His talent as a research administrator appeared early, and he quickly rose through the ranks of the CNRS, France's national research agency, becoming its director-general in 1969 and initiating a modernization of the agency. He was one of the founders of the European Science Foundation, based in Strasbourg, and was its first chairman from 1979 to 1984 , and from 1994 to 1996 he was president of the board of CERN. Janez Potocnik, the European Union research commissioner, paid tribute to Curien's efforts: "If something like a scientific Europe exists today, it is in great part thanks to him. He has played a key role in the history of European scientific cooperation.”

Curien's destiny as an architect of European space policy was to be shaped by his time as head of France's space agency, the CNES, during 1976-84, and his overlapping role as the first chairman of the board of ESA from 1981 to 1984 . Curien was concerned that the United States and Russia would dominate the space industry, and believed that Europe had to have its own independent capacity to launch satellites. He and Roy Gibson, ESA's first director-general, persuaded other countries to join ESA by creating the system of 'just returns' for industrial contracts. He oversaw the first launch of Ariane, and decided to create Arianespace.

Curien also played a critical role in the creation of ESA's flagship space science programme at a ministerial conference in Rome in 1985. Roger Bonnet, who headed ESA's science division from 1983 to 2001, remembers how, with the conference deadlocked, Curien came back from lunching with ministers opposed to the costs of the new programme with a deal giving it a massive $5 \%$ annual increase in budget for the next ten years. "Curien's diplomatic skills had a big effect on the birth of European space science," says Bonnet.

At the same time, Curien launched France into Earth observation with the SPOT series of satellites, and oversaw the setting up of the European Astronaut Corps. Less successful were his dreams for a European space shuttle, Hermes. With the costs of the craft soaring, Curien, in his second spell as science minister from 1988 to 1993 , did not hesitate to cancel what had been his own brainchild. Curien oversaw many of the heady days of Europe's fledgling space programme. Following the launch of the first Ariane above the jungle in Guiana in 1979, he and his colleagues celebrated with a tropical snowball fight, using the liquid hydrogen and oxygen dispensed from Ariane's fuel tanks.

It was after another successful rocket launch in Kourou that Curien caught the eye of Laurent Fabius. Curien was later to remark, "I climbed onto a barrel to say a few words as was the custom, and was welcomed by thunderous applause... Fabius, who had to create a new government, said that if all it took was for me to climb onto a barrel to be acclaimed, I would be a very popular minister."

Curien oversaw a massive investment in French research by Mitterrand, with spending on science rising from $1.97 \%$ of gross domestic product in 1981 to $2.42 \%$ in 1992 . This and a raft of reforms reorganizing the research agencies were enshrined in a 1982 law on science, which made research a national priority and underpinned a resurgence of French science in the 1980s. Curien was appreciated across the political spectrum, and for example was nominated as chair of the national scientific council of defence in 1986 by the neo-Gaullist government of Jacques Chirac, while at the same time being chairman of a campaign for the reelection of Mitterrand in the poll of 1988.

Following Curien's death, Jean-Pierre Raffarin, Chirac's current prime minister, spoke for both the political and scientific communities in France: Curien was, he said, "a man of conviction who knew how to overcome all divisions in the national interest". Declan Butler Declan Butler is a senior reporter for Nature based in Paris. 